\title{
A PROTEÇÃO OFERECIDA PELO SISTEMA DE PROPRIEDADE INDUSTRIAL AO TRADE DRESS NO BRASIL*
}

\author{
Karoline Pache Martins** \\ André Pedreira Ibañez****
}

\section{RESUMO}

Nesse artigo estudar-se-á a proteção oferecida pelo sistema de propriedade industrial ao trade dress no Brasil. 0 trade dress ou conjunto-imagem é a roupagem com a qual o produto ou o estabelecimento se apresenta ao mercado. Tal instituto, embora já não seja novidade em outros países como os Estados Unidos, não possui proteção legal no Brasil, tampouco é reconhecido por lei. Contudo, é um tema atual e que vem sendo cada vez mais utilizado pelos agentes econômicos para captar clientela e, portanto, possui alto valor. Daí a importância de se encontrar proteção a este instituto que vem sendo violado por concorrentes. Concluiu-se com a pesquisa deste trabalho que a doutrina vem reconhecendo a possibilidade de se conferir a proteção ao instituto caso comprovada a existência de atos de concorrência desleal, com base na convenção da união de Paris e no que dispõe a lei de propriedade industrial acerca do sistema de concorrência desleal. Verificou-se, portanto, que a ausência de previsão e proteção legal é de um lado um problema, e de outro uma liberdade, porque não limita as formas de trade dress que poderão surgir.

Palavras-chave: Propriedade industrial. Direito autoral. Trade dress. Conjunto-imagem. Concorrência desleal. Ausência de proteção legal. Propriedade intellectual.

* Artigo apresentado ao Curso de Bacharelado em Direito do Centro Universitário Metodista - IPA, como requisito parcial para obtenção do Grau de Bacharel em Direito.

** Graduanda do Curso de Bacharelado em Direito do Centro Universitário Metodista - IPA.

*** Orientador do artigo, Doutor em Direito e professor do Curso de Bacharelado em Direito do Centro Universitário Metodista - IPA. 


\section{THE PROTECTION OFFERED BY THE INDUSTRIAL PROP- ERTY SYSTEM TO TRADE DRESS IN BRAZIL}

\section{ABSTRACT}

In this article we propose to study the protection offered by the industrial property system to the trade dress in Brazil. The trade dress is the clothing with which the product or establishment is presented to the market. Such an institute, although not new in other countries such as the United States, does not have legal protection in Brazil, nor is it recognized by law. However, it is a current theme and is being increasingly used by economic agents to attract customers and therefore has a high value. Hence the importance of finding protection for this institute that has been violated by competitors. It was concluded with the research of this work that the doctrine has been recognizing the possibility of granting the protection to the institute if proven the existence of acts of unfair competition, based on the convention of the union of Paris and what disposes the industrial property law about of the unfair competition system. It was found, therefore, that the absence of legal prediction and protection is on the one hand a problem, and on the other a freedom, because it does not limit the forms of trade dress that may arise.

Key words:Industrial property. Business law. Trade dress. Set-image. Unfair competition. Lack of legal protection.

\section{INTRODUÇÃO}

0 presente trabalho tem como objetivo identificar como se dá a proteção conferida ao instituto do trade dress, ante a ausência de previsão legal. A análise buscará encontrar qual o meio eficaz dentro do ramo da propriedade industrial para alcançar a proteção do titular do direito e a responsabilização do agente econômico copiador.

No primeiro capítulo serão analisados os aspectos gerais da propriedade industrial, para que após possa ser aprofundado o tema. Em seguida, estudar-se-á os principais pontos acerca do instituto do trade dress, tais como origem do instituto, definições e características. Logo após, será explorada a questão da concorrência desleal e suas consequências, para que, ao final, seja 
possível concluir por alguma solução ao problema apresentado.

Cabe dizer que não há no ordenamento jurídico brasileiro previsão sobre o instituto do trade dress. Entretanto, isto não significa que o empresário que vê o seu conjunto imagem violado não possa buscar algum modo de defender este bem imaterial tão valioso.

O trade dress, também chamado de "conjunto-imagem" do produto ou do estabelecimento, são as características e traços próprios criados pelo titular, a fim de destacar o produto ou estabelecimento dos demais existentes no mercado. Pode-se apontar diversos casos de trade dress de sucesso no mercado, tais como: o vermelho e amarelo das lanchonetes Mc Donald's; o Azul e Amarelo dos postos de combustíveis Ipiranga, entre outros. Com o fito de ilustrar, abaixo imagens dos estabelecimentos acima citados.

Fotografia 1 - Estabelecimento Mc Donald's ${ }^{1}$

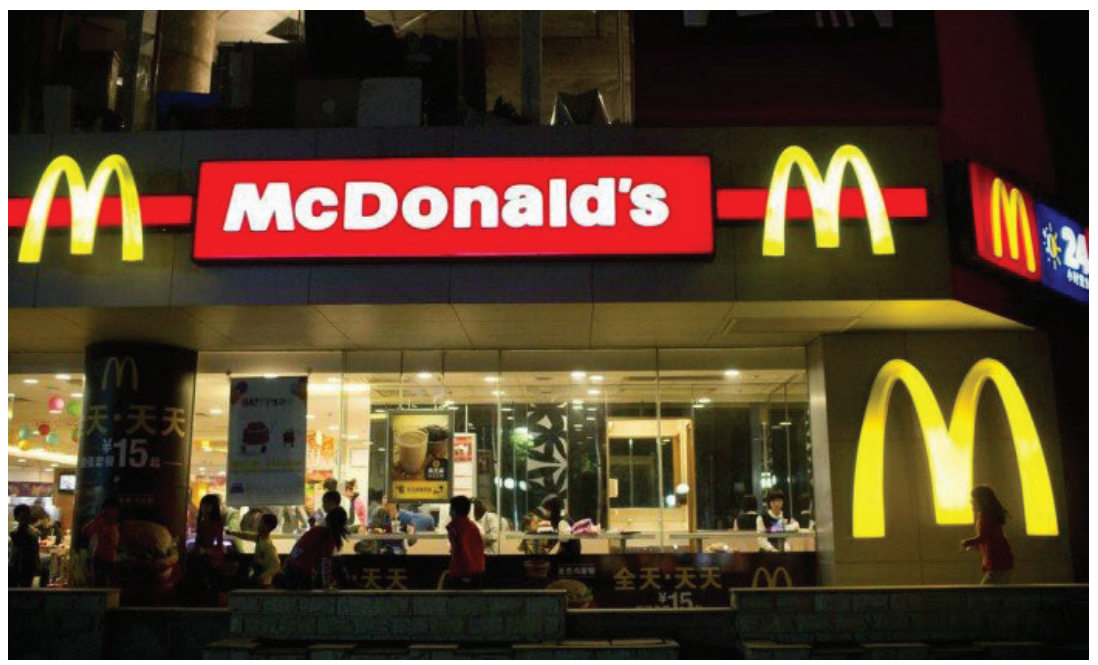

Imagem disponível em https://oglobo.globo.com/economia/apos-escandalo-de-carne-vencida-mcdonalds-aposta-em-marketing-com-jogos-on-linena-china-14596357, acesso em 08/10/2018. 
Fotografia 2 - Estabelecimento do posto Ipiranga ${ }^{2}$

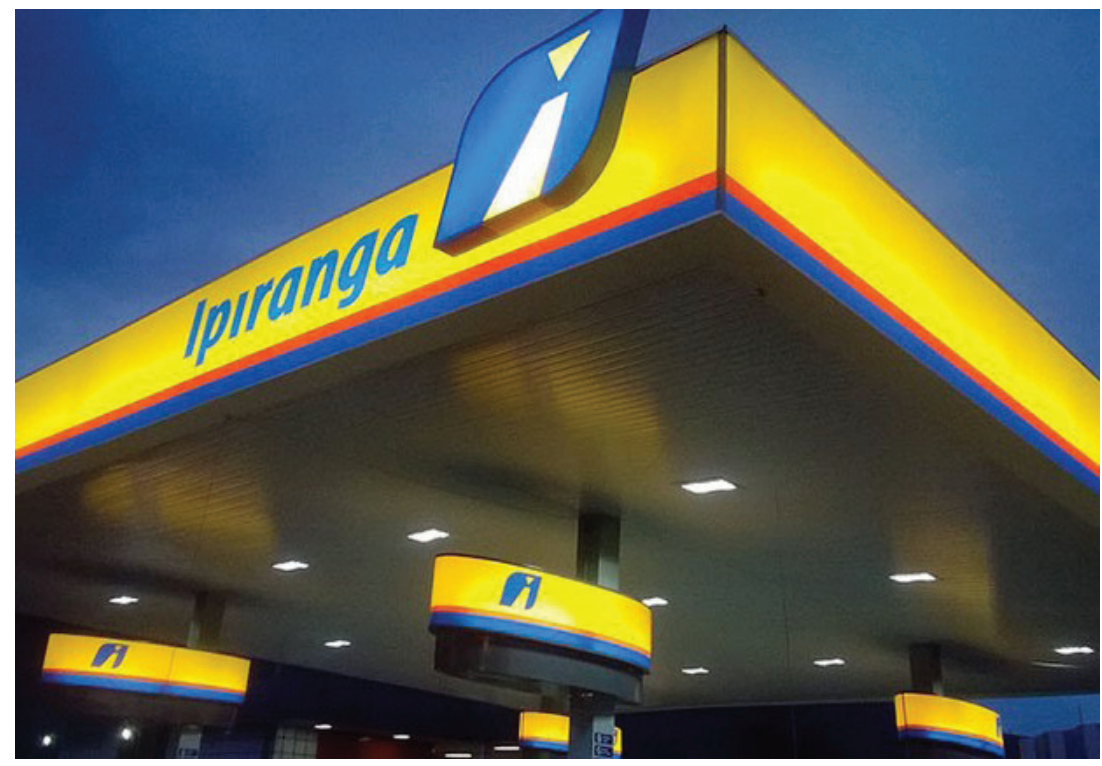

Conforme se verá, tais características não são registráveis em órgão governamental. Ocorre que alguns empresários, vendo o sucesso dos concorrentes, passaram a usar o trade dress alheio, sob o fundamento de que não há previsão legal para o instituto, e que, com isso, não haveria conduta ilícita.

Contudo, os doutrinadores passaram a defender a utilização do instituto da concorrência desleal para coibir tal conduta. Ora, se o oponente passa a utilizar o conjunto-imagem do outro, não se pode dizer que está embasado nas boas práticas de concorrência.

Assim, tal fundamento passou a ser aceito, consagrando o instituto da concorrência desleal como meio de se coibir a cópia do trade dress alheio, desde que comprovada a existência de prática de atos de desleais nas práticas comerciais.

2 Imagem disponível em https://epocanegocios.globo.com/Empresa/noticia/2017/08/cade-recomenda-condenacao-de-ale-e-ipiranga-por-cartel-emcidade-de-santa-catarina.html, acesso em 08/10/2018. 


\section{NOÇÕES SOBRE PROPRIEDADE INDUSTRIAL}

0 direito da propriedade industrial é uma das espécies, junto com o direito de autor, do gênero propriedade intelectual. Este trata de tutelar todos os bens que decorrem da atividade criadora do homem, da sua capacidade intelectual. Quando os bens de natureza intelectual interessam aos agentes econômicos, são eles tutelados pelo direito da propriedade industrial.

Fazendo uma breve retrospectiva histórica, a primeira legislação no Brasil a tratar sobre o tema foi a Lei de Patentes de 28 de abril de 1809, promulgada por Dom João VI, que visava dentre outros objetivos, a dar preferência nas compras efetuadas pelo Estado e incentivar a produção industrial local mediante isenção de tarifas. ${ }^{3}$ Não obstante, esta lei era aplicada apenas à produção industrial brasileira, não abrangendo isenções para produções de estrangeiros. ${ }^{4} \mathrm{~A}$ aludida legislação foi a pioneira em estabelecer os requisitos da novidade e realidade do invento. Ainda, trouxe o privilégio de utilização por prazo limitado, de modo que, findo o prazo, a invenção poderia ser gozada por toda a coletividade. ${ }^{5}$

Posteriormente, a Constituição de 1824 assegurou aos inventores a propriedade de suas criações, matéria disposta dentre as garantias individuais relativas à propriedade. ${ }^{6}$ Em 1830, com o intuito de regular a disposição constante na Constituição, restou promulgada a Lei de 28 de agosto de 1830, a qual tratou sobre a concessão de privilégios e os direitos decorrentes. Tal lei trazia punição, em pecúnia, para aquele que violasse os direitos do criador, de modo que a multa se convertia em favor do prejudicado. ${ }^{7}$

\footnotetext{
3 BARBOSA, Denis Borges. Tratado de propriedade intelectual. v. 1, Rio de Janeiro: Lumen Juris, 2013. p. 11.

4 Idem.

5 CERQUEIRA, João da Gama. Tratado da propriedade industrial, v. 1, Rio de Janeiro:Revista Forense, 1946, p. 29.

$6 \quad$ Id., 1946, p.30.

$7 \quad$ Id., 1946, p.32.
} 
Em 1882 o Brasil participou das discussões e foi signatário de um tratado internacional sobre propriedade industrial, o qual tinha o objetivo de traçar parâmetros mínimos de proteção nas legislações nacionais dos países signatários, bem como exigir um tratamento igualitário para nacionais e estrangeiros. Esse tratado é chamado de Convenção União de Paris, a CUP. A partir daí o direito brasileiro não admite que sejam feitas quaisquer distinções entre brasileiros e estrangeiros no que se refere à propriedade industrial. ${ }^{8}$ Atualmente, as disposições de tratados acerca de propriedade industrial no Brasil tratam de igual forma as pessoas físicas e jurídicas, assim como as pessoas nacionais e estrangeiras. ${ }^{9}$

Sempre oportuno trazer a definição do Ilustre João da Gama Cerqueira ${ }^{10}$ acerca da definição de propriedade industrial, para quem:

A propriedade imaterial compreende, como vimos, a propriedade literária, cientifica e artística que, como o nome indica, abrange as produções intelectuais de domínio literário cientifico e artístico; e a propriedade industrial, que pode ser definida como o conjunto dos institutos que visam garantir os direitos do autor sobre as produções intelectuais do domínio da indústria e assegurar a lealdade e a concorrência comercial e industrial.

Para Fazio ${ }^{11}$ os direitos de propriedade industrial se tratam de um conjunto de princípios e normas voltados à manutenção da inviolabilidade da produção autoral. Ainda, segundo Denis Borges Barbosa ${ }^{12}$ a mais correta definição de propriedade industrial está disposta na Convenção de Paris de 1883, a qual estabelece em seu artigo primeiro, parágrafo segundo, “como conjunto de

8 COELHO, Fábio Ulhoa. Manual de direito comercial: direito de empresa. 28. ed. Ver., atual. e ampl. São Paulo, Editora Revista do Tribunais, 2016. p 98.

9 FAZZIO, Junior Waldo. Manual de direito comercial. 7. ed. São Paulo: Atlas, 2006. p. 124.

10 CERQUEIRA, João da Gama. Tratado da propriedade industrial. Rio de Janeiro: Revista Forense, 1946.

11 FAZZIO, op.cit., p. 124.

12 BARBOSA, op. cit., p. 8 
direitos que compreendem as patentes de invenção, os modelos de invenção, modelos de utilidade, desenhos ou modelos industriais, as marcas de fábrica ou de comércio, marcas de serviço, nome comercial, indicações de proveniência ou denominações de origem, assim como a repressão a concorrência desleal."

No entendimento de Pedro de Souza e Silva ${ }^{13}$, o direito da propriedade industrial é:

Os direitos de propriedade industrial correspondem a um reconhecimento do estado, que os concede de acordo com as condições de fundo e de forma por si estabelecidas. Esse reconhecimento exprime uma conciliação de interesses antagônicos: o do titular do direito, que pretende um monopólio, e o da coletividade, interessada no livre exercício do comércio e da indústria.

A propriedade industrial é regulada pela Lei no 9.279 de 14 de maio de 1996, também conhecida como LPI - Lei da Propriedade Industrial. A legislação dispõe em seu artigo $2^{\circ}$ sobre a proteção sobre os seguintes bens: patentes de invenção e de modelo de utilidade, concessão de registro de desenho industrial, concessão de registro de marca, repressão às falsas indicações geográficas e repressão à concorrência desleal.

O empresário titular de algum desses bens tem o direito de explorar o objeto economicamente com exclusividade, assim como aliená-los, como ocorre com os demais bens integrantes do estabelecimento empresarial. ${ }^{14} \mathrm{O}$ direito da propriedade indus-

13 SILVA, Pedro Sousa e. Direito comunitário e Propriedade Industrial: 0 princípio do esgotamento dos direitos. Coimbra: Coimbra, 1996. p. 17

14 O estabelecimento empresarial, segundo Cesare Vivante (VIVANTE, Cesare. Instituições de Direito Comercial; tradução e notas de Ricardo Rodrigues Gama. Campinas-SP: Ed. LZN, 2003, p. 135) se traduz em uma grande variedade de bens, uma universalidade de fato, constituída por vontade do comerciante, dos quais fazem parte: as coisas corpóreas, como as máquinas; os direitos de uso de marca, firma, denominação, etc; e os fornecimentos, que são a esperança de lucros futuros. 
trial é constitutivo de direito, assim, a proteção de tais bens se estabelece com o respectivo registro no órgão correspondente, o INPI - Instituto Nacional da Propriedade Industrial. ${ }^{15}$

O INPI é uma autarquia federal criada em 1970 e atualmente vinculada ao Ministério de Desenvolvimento, Indústria e Comércio. ${ }^{16}$ Só é possível, via de regra, buscar-se a tutela referente aos bens tutelados pela propriedade industrial se for obtida a concessão pelo órgão do INPI. ${ }^{17}$ Contudo, conforme se verá a seguir, é possível encontrar a proteção dos bens não registráveis se ficar configurada a existência de prática de concorrência desleal, também protegida por lei. Afinal, o artigo 2º da LPI consagra ser um dos objetivos da propriedade industrial a repressão a concorrência desleal. ${ }^{18}$

Importante tratar de maneira distinta cada um dos institutos do direito da propriedade industrial. Iniciando pela patente, segundo Fabio Ulhoa Coelho ${ }^{19}$ "diz respeito à invenção ou ao modelo de utilidade." A invenção, pode ser compreendida como algo novo, não compreendido do estado da técnica, ou seja, algo desconhecido até então e que traz o requisito da novidade. Já a patente de modelo de utilidade é concedida ao objeto de uso prático corpóreo que pode ser utilizado na indústria, que represente uma melhoria inovadora em algo pré-existente. Alguns doutrinadores afirmam que o modelo de utilidade é uma pequena invenção ${ }^{20}$.

Ambos os institutos gozam de proteção jurídica específica

15 COELHO, Fábio Ulhoa. Manual de direito comercial: direito de empresa. 23. ed. São Paulo, Saraiva, 2011. p. 107.

16 FAZZIO, op. cit., p 125.

17 COELHO, Fábio Ulhoa. Manual de direito comercial: direito de empresa- 28. ed. Ver., atual. E ampl.- São Paulo, Editora Revista do Tribunais, 2016. P. 93

18 Art. 2ํㅗ A proteção dos direitos relativos à propriedade industrial, considerado o seu interesse social e o desenvolvimento tecnológico e econômico do País, efetua-se mediante:

$[\ldots]$

$\mathrm{V}$ - repressão à concorrência desleal.

19 COELHO, 2016, op. cit., p. 93.

20 COELHO, 2016, op. cit., p. 93. 
e devem se submeter a alguns requisitos para que seja possível a obtenção da patente, tais como: novidade, atividade inventiva, aplicação industrial e não impedimento. A novidade significa que a criação seja desconhecida pela comunidade científica, técnica ou industrial. 0 requisito da atividade inventiva está descrito nos artigos 13 e 14 da Lei de Propriedade industrial. ${ }^{21}$

0 artigo 13 da LPI dispõe, sobre a invenção, que não pode se tratar de uma decorrência óbvia do estado de técnica. No que se refere ao modelo de utilidade, não pode decorrer de maneira comum ou vulgar do estado de técnica, o que deve ser avaliado mediante pareceres de especialistas no assunto. ${ }^{22}$

Em relação ao requisito da aplicação industrial, só poderá ser patenteada a invenção ou modelo de utilidade suscetível de utilização industrial, ou seja, que pode ser utilizado na prática, que tenha utilidade. Por último, o não impedimento significa que não pode haver proibição de lei acerca daquela determinada invenção ou modelo ${ }^{23}$. A patente extingue-se pela expiração do prazo; pela renúncia do titular; pela caducidade ou pela falta de pagamento anual no prazo estabelecido. Ocorrendo a extinção da patente o objeto será de domínio público, de modo que poderá ser utilizado pela coletividade a partir de então. ${ }^{24}$

De outro lado, o registro, que também é realizado pelo INPI, garante ao titular o direito de exploração e utilização exclusiva de marca e de desenho industrial. Também para a obtenção do respectivo registro é necessário a comprovação de alguns requisitos, que devem ser abordados de maneira específica. ${ }^{25}$

0 desenho industrial ou "design" de produtos deve atender aos requisitos da novidade, tal e qual se sujeitam as invenções e o modelo de utilidade. Contudo, deve restar comprovado, outros-

\footnotetext{
21 Ibidem, p. 107.

22 Ibidem, p. 107.

23 Ibidem, p. 107.

24 FAZZIO, 2006, op. cit., p. 136.

25 COELHO, 2011, op. cit., p. 112.
} 
sim, o requisito da originalidade, que impende em um requisito estético. Deve apresentar uma configuração própria, não encontrada em outros objetos, conforme disposto no artigo 91 da LPI.

Ainda, o desenho industrial deve comprovar o desimpedimento, previsto no artigo 100 da LPI. Pode-se entender como desenho impedido de registro aquele que contraria a moral ou aos bons costumes, ofende à honra de terceiros, etc. ${ }^{26}$

No que toca à marca, segundo Bruno Jorge Hammes, ela destina-se a identificar e distinguir os produtos e mercadoria de outros idênticos ou semelhantes. ${ }^{27}$ A marca deve obedecer a três requisitos para que obtenha o respectivo registro junto ao INPI, são eles: novidade relativa, não colidência com marca notória e não impedimento.

A novidade que se exige para uma marca é relativa e não absoluta como nos casos de patentes, isso porque a expressão linguística ou o signo identificado não precisam, necessariamente, serem uma invenção do empresário, mas sim o modo como passou a ser utilizado para comercializar o produto ou realizar o serviço. Por exemplo, o uso de uma maçã para ilustrar a marca de empresa de tecnologia tinha novidade relativa, ou seja, a maça não é desconhecida, mas até então, nenhuma empresa de tecnologia utilizava esse signo para se identificar. Hoje, nenhuma outra empresa de tecnologia poderá usar a maçã, dado que não há mais novidade nesse uso. ${ }^{28}$

Do mesmo modo, a marca que deseja registro não pode colidir com marca notoriamente conhecida, mesmo que esta última não possua registro no INPI, nos termos do artigo $126^{29}$

26 COELHO, 2011, op. cit., p. 112.

27 HAMMES, Bruno Jorge. 0 direito de propriedade intelectual. 3. ed. São Leopoldo: Unisinos, 2002.P. 357.

28 COELHO, 2011, op. cit., p. 113.

29 Art. 126. A marca notoriamente conhecida em seu ramo de atividade nos termos do art. 6ำ bis (I), da Convenção da União de Paris para Proteção da Propriedade Industrial, goza de proteção especial, independentemente de estar previamente depositada ou registrada no Brasil. 
da LPI. Ou seja, não é viável registrar no Brasil uma marca muito famosa no exterior que não seja registrada aqui. Isso porque o Brasil é signatário da CUP e se comprometeu a garantir proteção as marcas famosas não registradas aqui.

Por fim, o pretendente de registro da marca deve demonstrar o não impedimento. Neste sentido, estão impedidos de serem registrados como marca tudo aquilo que está proibido por lei, por exemplo, nome empresarial e nome fantasia alheios, signos genéricos ou meramente descritivos, armas oficiais do exército, etc. ${ }^{30}$ Como visto, a lei da propriedade industrial admite patentes de invenções e de modelos de utilidade, bem como registros de desenhos industriais, marcas e indicações geográficas ${ }^{31}$.

Relevante fazer uma breve diferenciação entre alguns institutos, com o objetivo de se sanar futuras obscuridades. São eles: nome empresarial, marca e trade dress.

0 nome empresarial visa a identificar o sujeito que exerce a empresa, tem seu registro efetuado na Junta Comercial respectiva e, portanto, goza de proteção jurídica específica. Já no que se refere à marca, objetiva de diferenciar produtos ou serviços ${ }^{32}$. Tome-se como exemplo a empresa BR Foods (nome empresarial), que possui diversas marcas, dentre elas a Sadia, que em seus produtos tem o trade dress do " $\mathrm{S}$ " e da embalagem vermelha.

30 COELHO, 2011, op. cit., p. 113.

31 Transcreve-se o art. $2^{\circ}$ da Lei de Propriedade industrial (Lei 9279/96): A proteção dos direitos relativos à propriedade industrial, considerado o seu interesse social e o desenvolvimento tecnológico e econômico do País, efetua-se mediante:

I- concessão de patentes de invenção e de modelo de utilidade;

II - concessão de registro de desenho industrial;

III - concessão de registro de marca;

IV - repressão às falsas indicações geográficas; e

$\mathrm{V}$ - repressão à concorrência desleal.

32 COELHO, 2011, op. cit., p. 113. 
0 registro da marca é efetuado no INPI, conforme já visto anteriormente, e portanto, goza de proteção jurídica. ${ }^{33}$ Desse modo, o nome empresarial e a marca não se confundem com o trade dress, que é representativo da vestimenta, do conjunto imagem de um produto, mas também de uma loja, ou até mesmo todo um conceito de um negócio.

Não há, pois, previsão relativa ao trade dress. E, enfim, o que é e qual é a origem deste instituto chamado trade dress?

\section{TRADE DRESS: ORIGEM, DEFINIÇÃO E CARACTERÍSTICAS}

Um dos elementos mais importantes para o exercício da atividade empresarial é a criatividade do titular, seja quanto à capacidade de introdução de novos e competitivos bens ou serviços para o mercado, seja quanto à arte de apresentar seus produtos ao público consumidor ${ }^{34}$.

Nessa esteira surge o trade dress, também conhecido como "conjunto-imagem", que é um traço peculiar do produto ou do estabelecimento que os diferencia dos demais existentes. ${ }^{35} \mathrm{Os}$ complexos símbolos, linhas, traços e demais elementos com que o empresário se apresenta e exibe seus produtos perante o público, é que, no fundo, compõem sua imagem frente ao mercado, propiciando a sua individualização e o direcionamento do consumidor para os seus produtos. ${ }^{36}$

33 COELHO, 2011, op. cit., p. 95

34 Bittar, Carlos Alberto e Bittar, Carlos Alberto Filho. Tutela dos direitos da personalidade e dos direitos autorais nas atividades empresariais. São Paulo: Editora Revista dos Tribunais, 1993. p 143.

35 MANARA, Cecília. A proteção jurídica do "trade dress" ou "conjunto -imagem! Rio de Janeiro: Lumen Juris, 2008.

36 BITTAR, Carlos Alberto; BITTAR FILHO, Carlos Alberto. Tutela dos direitos da personalidade e dos direitos autorais nas atividades empresariais. São Paulo, Editora Revista dos Tribunais, 1993. p 145. 
Segundo Vinicius de Almeida Xavier ${ }^{37}$ o trade dress "consiste na identidade visual corporativa e sua função está em expressar a imagem que a empresa quer representar para o mercado". Imprescindível trazer o entendimento da doutrina clássica de Tinoco $^{38}$, para quem o:

Trade dress" é a imagem total do negócio; num sentido bem geral é o "look and feel", isto é, o ver e o sentir do negócio; é o meio pelo qual o produto é apresentado ao mercado; é o identificador da origem [...] o "trade dress" compreende uma única seleção de elementos que imediatamente estabelecem que o produto se distancia dos outros por isso que se torna inconfundível.

Logo, o trade dress é o meio pelo qual o produto é apresentado ao mercado, podendo se tratar da embalagem, combinação de cores com que se apresenta, os métodos de comercialização, as maneiras de sua divulgação, o desenho e/ou estilização interna ou externa do estabelecimento e componentes do produto. ${ }^{39}$

Portanto, procura-se no trade dress um modo de trazer destaque ao produto oferecido ou ao estabelecimento empresarial. Daí surgiram as características particulares de estabelecimentos como cores e até mesmo cheiros característicos. Nesse sentido, na sociedade moderna os estabelecimentos passaram a se utilizar do trade dress para movimentar o negócio, de modo que o conjunto visual do estabelecimento não deixasse margem para dúvida de qual se trata, o que impende na captação da uma clientela específica. ${ }^{40}$

37 XAVIER, Vinicius de Almeida. As possibilidades de proteção ao trade dress. Direito \& Justiça, [s.l.], v. 41, n. 2, p. 248-263, 29 jul, 2015. EDIPUCRS. http:// dx.doi.org/10.15448/1984-7718.2015.2.13642.

38 SOARES, José Carlos Tinoco. Concorrência desleal: Trade Dress e/ou Conjunto-Imagem (visual do objeto, do produto, de sua exteriorização e do estabelecimento). São Paulo: Ed. Do Autor, 2004. p. 213.

39 Ibidem, 2004, p. 107.

40 MANARA, Cecília. A proteção jurídica do "trade dress" ou "conjunto-imagem!. Rio de Janeiro: Lumen Juris, 2008. p 5. 
Não se pode limitar o trade dress ao visual interno ou externo do estabelecimento, tampouco aos seus pertences e disposição de mobílias, na medida em que a mente humana poderá vir a criar outras formas de apresentação que deverão receber a mesma proteção. ${ }^{41}$

Nos Estados Unidos o trade dress já é bastante conhecido, assim como possui lei específica, o Lanham act. 0 primeiro caso a dar visibilidade ao instituto foi o "Two Pesos Inc. vs. Taco Cabana Inc.", em 1992 nos Estados Unidos. A empresa Taco Cabana Inc. era uma rede de restaurantes de comida mexicana, conhecida por seu visual característico, em razão de letreiros utilizados no ambiente externo de todos os estabelecimentos. 0 concorrente, Two Pesos, rede de restaurantes do mesmo ramo, visualizando o sucesso do oponente, começou a utilizar de ambientes muito parecidos em seus estabelecimentos, e consequentemente, apoderou-se de certa clientela do rival $^{42}$. Veja-se a semelhança entre os estabelecimentos naquela época:

Fotografia 3: Taco Cabana ${ }^{43}$

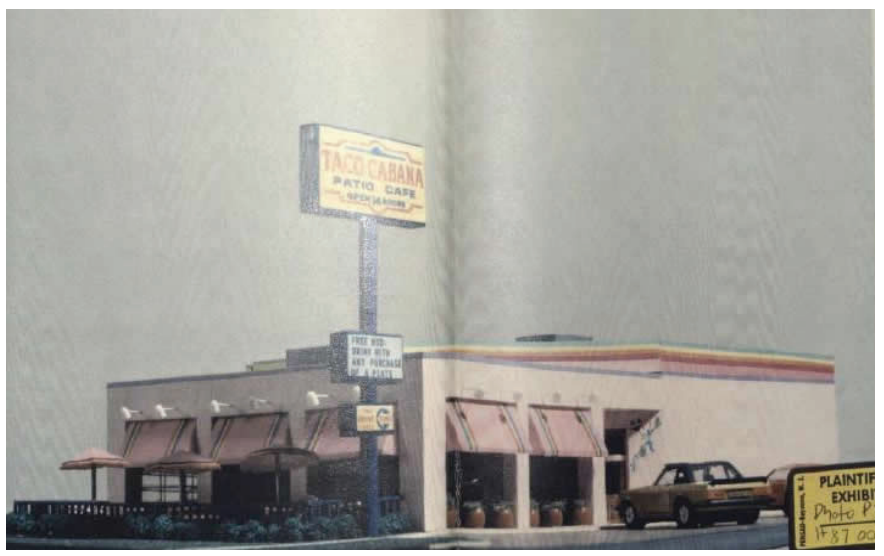

41 SOARES, 2004, São Paulo. p. 107.

42 MANARA, 2008, op. cit., p. 6.

43 Acessado em https://courses2.cit.cornell.edu/sociallaw/student_projects/ Tradedresspage2.html, em 08/10/2018. 
Fotografia 4 - Two Pesos ${ }^{44}$

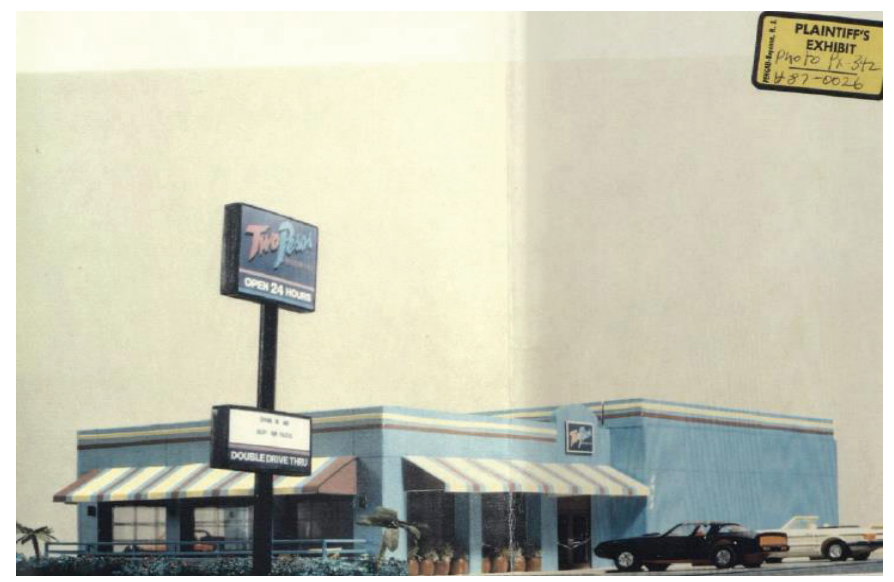

A empresa lesada ingressou com ação judicial em desfavor da concorrente, que chegou até a Suprema Corte dos Estados Unidos. Ao final, a Corte americana deu procedência à causa ajuizada e enfatizou que o trade dress deve ser considerado como "a imagem total do negócio", também sendo passível de danos. ${ }^{45}$

Após este precedente, a legislação americana dispôs que para ser passível de proteção, o trade dress deveria ser inerentemente distintivo, ou seja, ser secundário da marca. Entendia-se como inerentemente distintivo o desenho que fosse ao mesmo tempo único, usual e imprevisto, e que o consumidor pudesse associar automaticamente a uma marca em particular. ${ }^{46}$

Em meados de 1998 foi proposta alteração no diploma legal que trata sobre propriedade industrial nos Estados Unidos. A section 45 of the lanham act definiu o trade dress como a imagem total ou a aparência geral de um produto ou serviço, incluindo, mas não limitando, a desenho da embalagem, rótulos, recipientes,

\footnotetext{
$44 \quad$ Acessado em https://courses2.cit.cornell.edu/sociallaw/student_projects/ Tradedresspage2.html, em 08/10/2018.

45 MANARA, 2008, op. cit., p. 6.

46 SOARES, 2004, op. cit., p. 107.
} 
mostruários, decoração, desenho do produto, característica do produto ou a combinação de características do produto. ${ }^{47}$

No Brasil, embora os inúmeros casos de violação do instituto, ainda não há legislação acerca do tema, o que certamente gera instabilidade nas relações jurídicas. Importante referir, neste aspecto, que não são poucos os atos objetivando o comparecimento ao mercado com os mesmos ou similares produtos do concorrente, os quais são utilizados visando a se locupletar da criatividade alheia sob o manto da obscuridade ou da perspicácia. Daí a importância do instituto da concorrência desleal, cujos limites até hoje não foram fixados. ${ }^{48}$

Quanto à natureza jurídica do trade dress, em razão de se tratar de um conjunto de direitos de natureza intelectual, pode pertencer, a depender do caso, aos direitos de autor ou aos direitos de propriedade industrial ${ }^{49}$.Sua origem está pautada na necessidade do empresário de buscar a diferenciação de seu produto ou estabelecimento em detrimento dos demais, considerando a grande concorrência havida na sociedade atual. ${ }^{50}$

Logicamente que os casos de imitação de trade dress, com o fito de captar a clientela do concorrente, não tardaram a surgir. Diante deste cenário e da ausência de órgão registral, passou-se a se buscar um modo de proteger este bem da propriedade industrial, na medida em que é bem que agrega grande valor ao estabelecimento empresarial $^{51}$, integrando o seu aviamento ${ }^{52}$.

47 SOARES, 2004, op. cit., p. 101.

48 SOARES, 2004, op. cit., p. 15.

49 MANARA, 2008, op. cit., p. 6.

50 XAVIER, Vinicius de Almeida. As possibilidades de proteção ao trade dress. Direito \& Justiça, [s.l.], v. 41, n. 2, p. 248-263, 29 jul. 2015. EDIPUCRS. http://dx.doi.org/10.15448/1984-7718.2015.2.13642.

51 Ibidem.

52 S egundo Fábio Ulhoa Coelho (COELHO, Fábio Ulhoa. Curso de direito comercial, volume 1: direito de empresa. 18. Ed. São Paulo, Editora Saraiva, 2014. p.169) o aviamento se trata das perspectivas de lucratividade da empresa em razão da racional organização dos bens do estabelecimento pelo empresário. 


\section{TUTELA DO TRADE DRESS PELO SISTEMA DA CON- CORRÊNCIA DESLEAL}

De maneira preliminar, pode-se dizer que existe concorrência desleal em toda ação do concorrente que se aproveita indevidamente de criação ou de elemento integrante do aviamento alheio, para captar, sem esforço próprio, a respectiva clientela. ${ }^{53}$

Domina o mundo negocial o princípio da honestidade, requisito necessário ao regime da livre concorrência, ao qual se associa a lealdade, voltado especialmente para o respeito e defesa da concorrência como colunas principais. ${ }^{54}$

0 instituto da concorrência desleal visa a diminuir os abusos causados em virtude do princípio da livre concorrência ${ }^{55}$, que é um dos basilares da ordem econômica, com expressa previsão no artigo 170, inciso IV da Constituição Federal de $1988^{56}$.

Logo, tem como objetivo coibir determinados atos que, praticados por pessoas concorrentes, desrespeitam as regras do jogo, turbando o livre funcionamento do mercado e causando prejuízos para os legítimos titulares dos direitos violados. Tais ações, quando incorretas, imorais ou contrárias às normas que imperam no comércio podem refletir-se negativamente na esfera da concorrência ${ }^{57}$.

Surgem, portanto, diferentes procedimentos turbadores dos negócios, resultando em prejuízos morais ou patrimoniais a outros comerciantes ou industriais ou, até mesmo aos consumidores. Trata-se de uma forma especial de abuso de direito, também chamado pela doutrina de "abuso de livre concorrência". ${ }^{58}$

53 BITTAR, Carlos Alberto. Teoria e prática da concorrência desleal. São Paulo, Saraiva, 1989. p. 37.

54 Ibidem, p. 33.

55 SOARES, 2004, op. cit., p. 14.

56 Art. 170. A ordem econômica, fundada na valorização do trabalho humano e na livre iniciativa, tem por fim assegurar a todos existência digna, conforme os ditames da justiça social, observados os seguintes princípios: [...]

IV - livre concorrência;

57 SOARES, 2004, op. cit., p. 16.

58 BITTAR, 1989, op. cit., p. 36. 
Daí surge a necessidade de coibição de tais condutas. No Brasil, a repressão à concorrência desleal está prevista no artigo 195 da Lei $9.279 / 96^{59}$, que assim dispõe:

Art. 195. Comete crime de concorrência desleal quem:

I - publica, por qualquer meio, falsa afirmação, em detrimento de concorrente, com o fim de obter vantagem;

II - presta ou divulga, acerca de concorrente, falsa informação, com o fim de obter vantagem;

III - emprega meio fraudulento, para desviar, em proveito próprio ou alheio, clientela de outrem;

IV - usa expressão ou sinal de propaganda alheios, ou os imita, de modo a criar confusão entre os produtos ou estabelecimentos;

V - usa, indevidamente, nome comercial, título de estabelecimento ou insígnia alheios ou vende, expõe ou oferece à venda ou tem em estoque produto com essas referências;

VI - substitui, pelo seu próprio nome ou razão social, em produto de outrem, o nome ou razão social deste, sem o seu consentimento;

VII - atribui-se, como meio de propaganda, recompensa ou distinção que não obteve;

VIII - vende ou expõe ou oferece à venda, em recipiente ou invólucro de outrem, produto adulterado ou falsificado, ou dele se utiliza para negociar com produto da mesma espécie, embora não adulterado ou falsificado, se o fato não constitui crime mais grave;

IX - dá ou promete dinheiro ou outra utilidade a empregado de concorrente, para que o empregado, faltando ao dever do emprego, lhe proporcione vantagem;

$\mathrm{X}$ - recebe dinheiro ou outra utilidade, ou aceita promessa de paga ou recompensa, para, faltando ao dever de empregado, proporcionar vantagem a concorrente do empregador;

XI - divulga, explora ou utiliza-se, sem autorização, de conhecimentos, informações ou dados confidenciais, utilizáveis na indústria, comércio ou prestação de serviços, excluídos aqueles que sejam de

59 Disp. Em http://www.planalto.gov.br/ccivil_03/Leis/L9279.htm 
conhecimento público ou que sejam evidentes para um técnico no assunto, a que teve acesso mediante relação contratual ou empregatícia, mesmo após o término do contrato;

XII - divulga, explora ou utiliza-se, sem autorização, de conhecimentos ou informações a que se refere o inciso anterior, obtidos por meios ilícitos ou a que teve acesso mediante fraude; ou

XIII - vende, expõe ou oferece à venda produto, declarando ser objeto de patente depositada, ou concedida, ou de desenho industrial registrado, que não o seja, ou menciona-o, em anúncio ou papel comercial, como depositado ou patenteado, ou registrado, sem o ser;

XIV - divulga, explora ou utiliza-se, sem autorização, de resultados de testes ou outros dados não divulgados, cuja elaboração envolva esforço considerável e que tenham sido apresentados a entidades governamentais como condição para aprovar a comercialização de produtos.

Pena - detenção, de 3 (três) meses a 1 (um) ano, ou multa.

$\S 1^{\text {}}$ Inclui-se nas hipóteses a que se referem os incisos XI e XII o empregador, sócio ou administrador da empresa, que incorrer nas tipificações estabelecidas nos mencionados dispositivos.

$\S 2$ 응 0 disposto no inciso XIV não se aplica quanto à divulgação por órgão governamental competente para autorizar a comercialização de produto, quando necessário para proteger o público.

Conforme se verifica, o aludido artigo elenca uma série de condutas passíveis de serem consideradas desleais, bem como tipifica como crime algumas delas ${ }^{60}$. Também, a convenção da União de Paris, da qual o Brasil é signatário, promulgada através do Decreto Lei no 635 de 21/08/1992, se dispõe a conceituar a concorrência desleal, embora de maneira genérica ${ }^{61}$, da seguinte forma, em seu artigo 10- bis $^{62}$ :

\footnotetext{
60 SOARES, 2004, op. cit., p. 50.

61 SOARES, 2004, op. cit., p. 194.

62 http://www.inpi.gov.br/legislacao-1/cup.pdf
} 
Art. 10- bis

(1) Os países da União obrigam-se a assegurar aos nacionais dos países da União proteção efetiva contra a concorrência desleal.

(2) Constitui ato de concorrência desleal qualquer ato de concorrência contrário aos usos honestos em matéria industrial ou comercial.

(3) Deverão proibir-se particularmente:

1 o Todos os atos suscetíveis de, por qualquer meio, estabelecer confusão com o estabelecimento, os produtos ou a atividade industrial ou comercial de um concorrente;

2 o As falsas alegações no exercício do comércio, suscetíveis de desacreditar o estabelecimento, os produtos ou a atividade industrial ou comercial de um concorrente;

3 o As indicações ou alegações cuja utilização no exercício do comércio seja suscetível de induzir o público em erro sobre a natureza, modo de fabricação, características, possibilidades de utilização ou quantidade das mercadorias

Assim, nota-se que a convenção dita de maneira superficial o instituto, dando liberdade aos Países signatários para legislarem internamente sobre a matéria de concorrência desleal ${ }^{63}$. A livre concorrência, como qualquer liberdade, não é irrestrita, e o seu exercício encontra limites nos direitos dos outros concorrentes, os quais devem ser respeitados. Não respeitados esses limites surge a concorrência desleal como um inibidor. ${ }^{64}$

Em que pese muitos bens imateriais sejam tutelados por normas específicas (tome-se como exemplo as patentes, marcas e direito de autor) e gozem de exclusividade absoluta, alguns bens não recebem do legislador o tratamento próprio. Esses bens passam a receber, entretanto, tratamento e proteção genérica através das normas de repressão à concorrência desleal. Contudo,

63 SOARES, 2004, op. cit., p. 194

64 SOARES, 2004, op. cit., p. 14 
a proteção genérica dependerá da comprovação de situação de concorrência entre os agentes. ${ }^{65}$

Em qualquer sistema jurídico que haja liberdade de iniciativa, ou seja, acesso livre à atividade econômica e livre concorrência, surgem interesses econômicos sem condicionamento primário de direito. ${ }^{66}$ Se por um lado a livre concorrência representa um facilitador outorgado pelo Estado, por outro, limita a iniciativa, na medida em que é restrita a algumas exceções, dentre elas a propriedade industrial. Assim, é permitida a competição, desde que o objeto da competição não seja protegido. Pode-se dizer, portanto, que a livre concorrência também visa que o empresário titular não obtenha vantagem econômica mediante ardil. ${ }^{67}$

Em matéria de concorrência desleal é importante destacar que abrange tanto normas de direito público como de direito privado. Por exemplo, no que se refere ao direito privado, tutela diretamente o estabelecimento e aviamento, enquanto o direito público coíbe as infrações de abuso de poder econômico. ${ }^{68}$

Para que reste configurada a existência de concorrência desleal, devem ser considerados alguns pressupostos. Em primeiro, deve-se analisar se realmente existe a concorrência. Se tratando de concorrência desleal não há de se falar em lesão se sequer existir a concorrência. E mais: essa competição deve ser exercida, pois dois competidores que não se agridem não podem alegar deslealdade concorrencial ${ }^{69}$.

65 SILVEIRA, Newton. Propriedade intelectual: propriedade industrial: direito de autor, software, cultivares, nome empresarial, abuso de patentes. 5. ed. Barueri: Manoele, 2014. p.103.

66 BARBOSA, Denis Borges: Uma introdução à propriedade intelectual, 2. Ed. Rio de Janeiro: Lumen Juris, 2003. p. 271.

67 FALCONE, Bruno. Propriedade industrial e defesa da concorrência: convergência principiológica. Curitiba: Juruá, 2013. P. 217.

68 SILVEIRA, 2014, op. cit., p.102.

69 BARBOSA, Denis Borges: Uma introdução à propriedade intelectual, 2. ed. Rio de Janeiro: Lumen Juris, 2003. p. 274. 
Para Bittar, para que fique configurada a concorrência desleal $^{70}$ devem ser observadas as seguintes premissas: culpa do agente, sendo desnecessária a ocorrência de dolo ou fraude; irrelevância de verificação de dano em concreto; existência de clientela; e por fim, ato suscetível de repreensão.

Outro requisito necessário para a caracterização da concorrência desleal é a atualidade da competição. Ou seja, para a demonstração do comportamento competitivo reprovável é necessária a atualidade na competição. ${ }^{71}$

Neste sentido, o que se entende por lealdade ou deslealdade resulta da conformidade ou não do comportamento do agente econômico ao padrão esperado. Logo, para se verificar a existência ou não de um comportamento desleal o parâmetro a ser utilizado não é legal, mas fático. É fundamental que os comportamentos sejam contrários aos usos honestos em matéria industrial ou comercial, apurados conforme o contexto fático de cada mercado, local e tempo. ${ }^{72}$

No que se refere ao dano sofrido, para a doutrina clássica, não se exige a sua concretização, bastando a possibilidade ou o perigo de sua superveniência. ${ }^{73}$

Desse modo, a tutela da concorrência desleal se mostrou efetiva para oferecer proteção ao agente econômico que tem o trade dress violado. Tal instituto encontra amparo na Lei de Propriedade Industrial, em seu artigo 209, que determina ${ }^{74}$ :

Fica ressalvado ao prejudicado o direito de haver perdas e danos em ressarcimento de prejuízos causados por atos de violação de direitos de propriedade industrial e atos de concorrência desleal não previstos nesta Lei, tendentes a prejudicar a

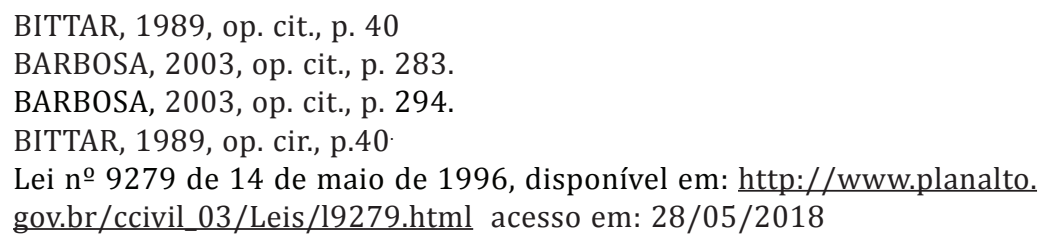


reputação ou os negócios alheios, a criar confusão entre estabelecimentos comerciais, industriais ou prestadores de serviço, ou entre os produtos e serviços postos no comércio.

Do mesmo modo, o disposto no artigo $5^{\circ}$, inciso XXIX da Constituição Federal de 1998 também serve à tutela do conjunto imagem, já que a regra determina proteção aos "outros signos distintivos" importantes para os exercentes de atividades econômicas. Veja-se o texto da regra:

A lei assegurará aos autores de inventos industriais privilégio temporário para sua utilização, bem como proteção às criações industriais, à propriedade das marcas, aos nomes de empresas e a outros signos distintivos, tendo em vista o interesse social e o desenvolvimento tecnológico e econômico do País.

Assim, restou conferida a proteção genérica imediata e suficiente em caso de imitação do trade dress por concorrentes, não se encontrando óbice à tutela reparadora por danos em razão da ausência de proteção legal específica. ${ }^{75}$ Claro que a previsão de tutela específica, com possibilidade registral, seria uma forma de tutela preventiva, que não existe no Brasil.

Nesse diapasão, oportuno referir o lúcido ensinamento de José de Oliveira Ascensão ${ }^{76}$ acerca da abrangência do instituto:

Neste sentido se diz que a concorrência desleal é supletiva em relação aos direitos privativos; permite chegar a zonas que estes não cobririam. Mas, por outro lado, havendo um direito privativo basta demonstrar a infração deste; enquanto que; se se recorre à concorrência desleal, se têm de satisfazer os pressupostos mais exigentes dessa figura.

75 GUSMÃO, Jose Roberto D'affonseca; H’ANENS, Laetitia Maria Alice Pablo. Breves comentários sobre a proteção ao trade dress no Brasil. Revista dos Tribunais, São Paulo, v. 1, n. 1, p. 585-597, mai/2012. Mensal.

76 ASCENSÃO, José de Oliveira. Concorrência desleal. Coimbra: Almedina, 2002. p.498. 
Ressalta Tinoco ${ }^{77}$ que nem sempre o nome do estabelecimento é o que sofre violação, na medida em que está protegido por registro. Por outro lado, os demais elementos tais como disposição de cores, mobília, uniforme dos vendedores sofrem o dano. Neste sentido, cumpre destacar o bem lançado trecho ${ }^{78}$ :

Para atingir esse resultado a que se refere o "conjunto visual intrínseco ou extrínseco" e/ou o "visual do estabelecimento", foi necessário o concurso de uma, várias ou mesmo inúmeras pessoas, as quais, do fruto de seu intelecto, retiraram, idealizaram e concluíram a sua obra, dando-se-lhe características próprias. Essas características próprias, não obstante realizadas para um estabelecimento vem sendo repetidas graças ao sucesso alcançado no primeiro, em outros, fazendo parte de um "todo" harmonioso.

Para fins de se conceituar a concorrência desleal, traz-se o entendimento de Tinoco, ${ }^{79}$ que entende possível ser utilizada como definição de concorrência desleal aquela consagrada na Convenção da União de Paris, que caracteriza como concorrência desleal as práticas desonestas na indústria e comércio. Para tanto, busca coibir qualquer ato que possa criar confusão, seja qual for o meio empregado.

No que se refere ao estabelecimento, uma das formas de concorrência desleal é a que provoca confusão entre dois estabelecimentos em razão da semelhança de fachadas e elementos característicos capazes de distingui-los. Deve ser observado, no momento de apreciação do caso, as circunstâncias havidas tais como a proximidade entre os estabelecimentos. ${ }^{80}$

77 SOARES, José Carlos Tinoco. Concorrência desleal. São Paulo: Resenha Tributária, 1990. p. 10.

78 Ibdem, 1990, p. 10.

79 Ibdem, 1990, p. 10.

80 CERQUEIRA, João da Gama Tratado de propriedade industrial. Volume II. Ver. Atual. Por Newton Silveira e Denis Borges Barbosa, Rio de Janeiro: Lumen Juris, 2012. p. 285. 
Em relação a produtos e mercadorias, segundo Cerqueira da Gama ${ }^{81}$ "obedecem aos mesmos princípios relativos às marcas de fábrica e do comércio". Portanto, podem ser utilizados alguns dos princípios aplicáveis às marcas para buscar a proteção do trade dress.

São diversas as formas de concorrência desleal, sendo as principais: atos de descrédito, atos de confusão, atos de aproveitamento e os atos enganosos. Verifica-se um ato de descrédito quando um oponente faz falsas afirmações ao mercado a fim de desacreditar o concorrente. Neste caso, a alegação do concorrente de que acredita ser verdadeira a afirmação não afasta a deslealdade do ato praticado, na medida em que restaria ainda a deslealdade de proferir informações graves sem ter o cuidado de as verificar. ${ }^{82}$

Já os atos de aproveitamento são aqueles no qual o agente econômico faz referência não autorizada de seu produto ao do concorrente, buscando benefício ilegítimo. E os atos enganosos se caracterizam quando o empresário faz falsas afirmações de si próprio para captar clientela. Este último ato tem como traço principal a falsidade das indicações e o engano ao consumidor. Deve-se ponderar se este ato enganoso é relevante a ponto de ser capaz de ludibriar o consumidor. ${ }^{83}$

Uma das práticas mais comuns de concorrência desleal realizadas, e que é de essencial compreensão para o estudo do trade dress, é o ato de confusão. 0 conceito de confusão pode ser em sentido amplo e em sentido estrito. Em sentido estrito, a confusão se caracteriza quando um concorrente confunde o cliente em relação à origem, fazendo acreditar ser sua determinada prestação de serviço, produto ou estabelecimento que na realidade não é. ${ }^{84}$

$81 \quad$ Ibdem, 2012. p. 285.

82 GONÇALVES, Luís M. Couto. Manual de direito industrial: patentes, marcas, concorrência desleal. Coimbra: Almedina, 2005. p. 354.

83 Ibdem, 2005. p. 357.

84 GONÇALVES, Luís M. Couto. Manual de direito industrial: patentes, marcas, concorrência desleal. Coimbra: Almedina, 2005. p. 353. 
Em sentido amplo, também chamada de confusão atípica, o consumidor não estabelece uma confusão quanto à origem, mas acredita existir qualquer relação, jurídica, econômica e comercial entre os agentes econômicos. ${ }^{85}$

Segundo Luís M. Couto Gonçalves ${ }^{86}$ podem existir três tipos de situação geradora de confusão: na primeira, com a utilização de sinais distintivos protegidos por direitos industriais, como o nome empresarial e a marca; a utilização de sinais suscetíveis de registro, mas que não foram registrados; e por fim, quando utilizado sinais ou meios distintivos não protegidos pela propriedade industrial. No último, verifica-se a hipótese do trade dress, que não possui proteção específica pelo sistema na propriedade industrial.

No mesmo sentido é o entendimento de José de Oliveira Ascensão ${ }^{87}$, o qual ressalta que a confusão pode ser caracterizada em relação a elementos que possuem direito privativo e também em relação a aqueles que não possuem.

Cabe assinalar que a prática da concorrência desleal gera ilícito civil, a ser reparado pelo instituto da responsabilidade civil daquele que praticou o dano, mas também gera lícito penal, já que há tipificação na própria LPI dos crimes de concorrência desleal. Portanto, a violação do trade dress pode ser coibida na esfera cível e criminal. ${ }^{88}$

Na maioria dos casos, o trade dress está em uma cor característica ou a disposição de mobília do estabelecimento, o que, per se, não enseja a possibilidade de registro. Assim sendo, o empresário fica à mercê do entendimento pessoal do julgador, que irá avaliar, conforme critérios subjetivos, a prática de concorrência desleal no caso.

$85 \quad$ Ibdem, 2005. p. 354.

86 Ibdem, 2005. p. 355.

87 ASCENSÃO, José de Oliveira. Concorrência desleal. Coimbra: Almedina, 2002. p. 498.

88 SOARES, José Carlos Tinoco. Concorrência desleal. São Paulo: Resenha Tributária, 1990. p. 196. 
Assim, para se atingir ao objetivo de proteção ao trade dress, não existirá melhor caminho que o do combate à concorrência desleal, não necessitando de comprovação de registro ou outra formalidade. ${ }^{89}$

\section{ESTUDO DE CASOS: PRECEDENTES QUE ILUSTRAM A PROTEÇÃO DISPENSADA AO TRADE DRESS}

Importante analisar alguns casos acerca do tema, a fim de entender como a jurisprudência pátria vêm interpretando e analisando os casos de violação ao conjunto-imagem.

Recentemente foi julgado o interessantíssimo recurso de apelação número 1093251-56.2017.8.26.010090 no Tribunal de Justiça de São Paulo. A empresa, em tese lesada, Unilever Brasil LTDA. ajuizou ação cominatória com pedido deindenização por perdas e danos e de tutela de urgência em face da oponente GFG Cosméticos Ltda. (Muriel) alegando que esta segunda estaria violando o conjunto imagem da embalagem do produto "Maisena" (amido de milho). A oponente colocou no mercado produtos para cabelo, tais como shampoos, cremes, etc., com a denominação de "Alisena", fazendo a associação com o produto Maisena, que é uma marca registrada, se fazendo passar por uma "Maisena capilar", produtos capilares de amido de milho.

A fim de visualizar a semelhança entre os produtos abaixo imagens de ambas as embalagens, veja-se:

89 SOARES, 2004, op. cit., p. 10228.

90 BRASIL. Tribunal de Justiça de São Paulo. Acórdão de Apelação no 1093251 56.2017.8.26.0100. Relator: Ricardo Negrão. São Paulo, SP de 2018. Dje. São Paulo, 18 set. 2018. 
Fotografia 5: amido de milho Maisena (Unilever Brasil Ltda.) ${ }^{91}$

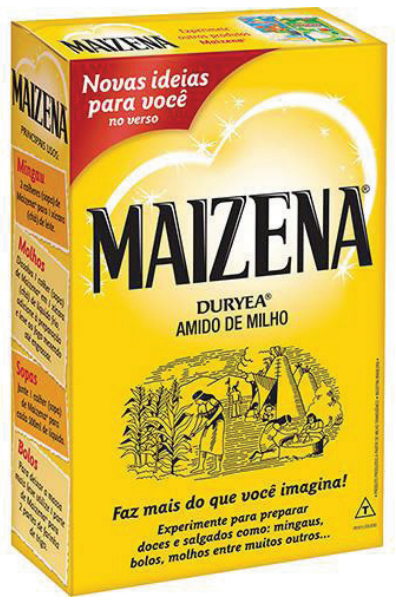

Fotografia 6: Shampoo de amido de milho (GFG Cosméticos Ltda.) ${ }^{92}$

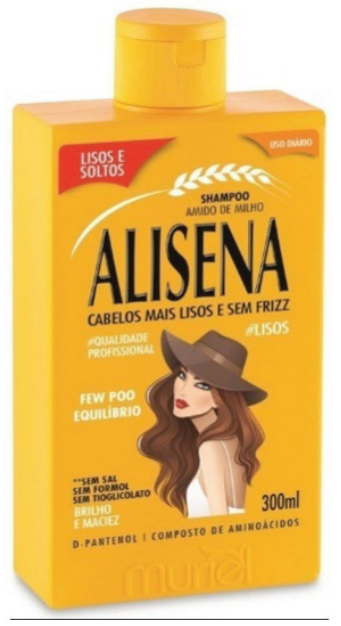

91 Imagem disponível emhttp://www.soubarato.com.br/produto/129320216/ amido-de-milho-maizena-500g, acessado em 08/10/2018.

92 Imagem disponível em https://www.lojaslivia.com.br/produto/shampoo-alisena-amido-de-milho-300-ml-lisos-e-soltos-83594, acessado em 08/10/2018. 
Observando-se ambas as embalagens, é visível a associação entre os produtos, em que pese as fabricantes não tenham qualquer envolvimento. A cor e o formato da embalagem, e até mesmo o nome do produto são muito semelhantes, capazes de induzir o consumidor em erro e causar confusão entre os produtos, apesar de um ser alimento o outro ser um cosmético.

Calha trazer trecho da obra de Bittar ${ }^{93}$, no qual se reflete sobre a importância da embalagem para o poder de decisão de compra do consumidor. Observe-se:

Ao compor o produto, como sua roupagem definitiva para consumo, a embalagem exerce a influência mais direta sobre o público geral, representando verdadeiro elo de comunicação final entre produtor e consumidor. Também como integrante de sua ornamentação, a embalagem atua como força atrativa imediata do consumidor, impondo-lhe, muitas vezes, pela excitabilidade provocada, o impulso aquisitivo, para ele até imperceptível ou mesmo inevitável. É decisivo, no ato da compra, o fator psicológico, razão pela qual uma embalagem convidativa pode arrebatar o consumidor e adquirir a sua preferência, mantendo-o fiel a determinado produto.

Insta salientar, que não obstante os produtos sejam de ramos distintos, deve-se sempre lembrar do que se entende por concorrência desleal. Será desleal qualquer comportamento com fins concorrenciais contrário às exigências de boa fé na concorrência. ${ }^{94}$ Tem-se um típico caso de confusão em sentido amplo. O consumidor passa a acreditar que a linha de shampoos tem uma relação com o amido de milho, quando na verdade não tem.

93 Bittar, Carlos Alberto e Bittar, Carlos Alberto Filho- Tutela dos direitos da personalidade e dos direitos autorais nas atividades empresariais. São Paulo: Revista dos Tribunais, 1993 p. 146.

94 GONÇALVES, Luís M. Couto. Manual de direito industrial: patentes, marcas, concorrência desleal, Coimbra: Almedina, 2005. p. 338. 
Ainda para Bittar, ${ }^{95}$ sobre a confusão entre os produtos, em seu entender, observa-se nestes casos:

a) anterioridade do produto concorrente;

b) existência de imitação;

c) suscetibilidade de estabelecer-se confusão entre os produtos.

Para este autor, a ação do oponente que causa confusão deve ser analisada à luz sobre o produto preexistente, ou seja, com o qual se objetive a assemelhação, para indução do público à sua procura.

Cabe acrescentar o lúcido parecer de Débora Portilho ${ }^{96}$ neste aspecto:

A concorrência desleal pode ocorrer de inúmeras formas, tantas quantas a imaginação humana permitir. Assim sendo, não importaria quão criativo fosse o legislador - do Brasil ou de qualquer outro país - ele jamais conseguiria elencar todos os atos e condutas ilícitas que poderiam ser praticados por um concorrente em detrimento de outrem.

Ações deste tipo, que se apropriam de criações estéticas utilizadas pelo concorrente, geram confusão no consumidor, seja na imitação do desenho, de figura, de símbolo ou de outro elemento identificador do rival ${ }^{97}$. Ainda, cabe trazer para destaque a questão da publicidade comparativa, que é visível no caso analisado, no qual a empresa de shampoos utiliza o trade dress da empresa de alimentos.

95 Bittar, Carlos Alberto. Teoria e prática da concorrência desleal. São Paulo: Saraiva, 1989. p. 54.

96 PORTILHO, Deborah. O projeto de lei do senado para coibir a concorrência parasitária: ou será o aproveitamento parasitário? Revista Científica Virtual da Escola Superior de Advocacia da Oab, SP, São Paulo, v., n. 9, p.18-35, jan. 2014. Disponível em: <http://www.dportilho.com.br/o-projeto-de-lei-dosenado-para-coibir-a-concorrencia-parasitaria-\%E2\%80\%93-ou-sera-o-aproveitamento-parasitario/>. Acesso em: 27 out. 2018.

97 BITTAR, 1989, op. cit., p. 54. 
Em relação à publicidade comparativa, importa na colocação de um produto ao lado de outro de forma ostensiva, obscura ou subliminar, produto esse que comumente logrou encontrar sucesso, para que possa aproveitar das divulgações do outro produto que está surgindo ou que, já existente no mercado, ainda não conquistou a preferência dos consumidores. É uma forma contumaz que buscam os concorrentes para trazer seu produto e/ou serviço para fazer aparição ao mercado. ${ }^{98}$

Seguindo-se com a análise do caso, o Magistrado sentenciante, da 33a ${ }^{a}$ Vara Cível do Foro Central da Comarca de São Paulo, entendeu que sequer era necessária a produção de provas, e julgou improcedentes os pedidos, ressaltando que não foram demonstrados prejuízos à empresa/autora, assim como considerou que os seguimentos explorados pelas empresas são diversos. Destacou ainda, que ambas as empresas possuíam registro de marca no INPI, devendo, se fosse o caso, ser desconstituída a marca violadora.

A lesada recorreu da referida sentença alegando a visibilidade da reprodução do conjunto visual, bem como a semelhança fonética e gráfica entre as embalagens, o que ocasionaria um "ar de família” entre os produtos. A empresa GFG Cosméticos Ltda. respondeu ao recurso sustentando que não havia qualquer associação, na medida em que as fabricantes exploravam seguimentos econômicos distintos, assim como que a estilização da embalagem pretende a diferenciação entre os produtos.

Ao julgar o recurso de apelação, o Desembargador Relator destacou que a controvérsia residia na apresentação visual das embalagens (conjunto-imagem), que expõe para o consumidor percepções muito semelhantes, ocasionando a associação entre os produtos. Ponderou que embora não haja proteção ao conjunto-imagem na legislação brasileira, o tema é tutelado pelos dispositivos que coíbem a prática de concorrência desleal (princi-

98 SOARES, 1990, op. cit., p. 21. 
palmente o artigo 195, III da Lei n. 9279/96) ${ }^{99}$, sendo que no caso concreto foi utilizado artifício que induz ao desvio da clientela.

Importante destacar, no que se refere à concorrência existente, que concorrentes não são apenas aqueles que estão no mesmo segmento de mercado e disputam o mesmo cliente. Pode haver concorrência em diversos níveis, inclusive entre empresas de segmentos distintos. ${ }^{100}$

Para a doutrina moderna, não há a necessidade de concorrência entre os agentes quando houver parasitismo, como se verificou no caso analisado. Em relação ao parasitismo, recentemente passou-se a discutir e coibir práticas anormais, com base nas normas de repressão à concorrência desleal, ainda que não configurados os pressupostos de repressão à concorrência desleal clássica, quer porque inexiste a relação de concorrência entre os agentes, quer porque ausente a possibilidade de confusão entre os agentes, produtos e serviços ${ }^{101}$.

Entende-se por concorrência parasitária o ato de um agente econômico tirar ou procurar tirar proveito das realizações pessoais do concorrente com renome legitimamente adquirido, mesmo que não se tenha a intenção de prejudicar. ${ }^{102}$ Assim, qualquer empresa que se valha de criações alheias pode ser classificada como "parasita" e também não há dúvidas de que essas empresas

99 Art. 195. Comete crime de concorrência desleal quem: [...]

III - emprega meio fraudulento, para desviar, em proveito próprio ou alheio, clientela de outrem;

100 PORTILHO, Deborah. O projeto de lei do senado para coibir a concorrência parasitária - ou será o aproveitamento parasitário? Revista Científica Virtual da Escola Superior de Advocacia da Oab-sp, São Paulo, , n. 9, p.18-35, jan. 2014. Disponível em: <http://www.dportilho.com.br/o-projeto-de-lei-dosenado-para-coibir-a-concorrencia-parasitaria-\%E2\%80\%93-ou-sera-o-aproveitamento-parasitario/>. Acesso em: 27 out. 2018.

101 JABUR, Wilson Pinheiro; SANTOS, Manoel J. Pereira dos. (coord.). Propriedade intelectual: criações industriais, segredos de negócio e concorrência desleal- São Paulo: Saraiva, 2007. p. 378

102 Ibidem. p. 378. 
tanto podem ser concorrentes como não concorrentes do titular da propriedade intelectual copiada ou imitada. ${ }^{103}$

A repressão à concorrência parasitária e ao aproveitamento parasitário está fundada nos princípios gerais de direitos relativos à boa-fé, na teoria do abuso da liberdade de comércio ${ }^{104}$.

Importante, ainda, fazer uma breve distinção entre concorrência parasitária e aproveitamento parasitário. A concorrência parasitária só ocorre entre concorrentes e é uma espécie do gênero concorrência desleal, o que já é uníssono entre a grande maioria dos doutrinadores. ${ }^{105}$

Já o aproveitamento parasitário, apesar de muitas vezes a expressão ser usada como sinônimo de concorrência parasitária, sua principal característica é a inexistência de concorrência entre as partes ${ }^{106}$.

Em prosseguimento ao caso, os julgadores não deixaram margem para dúvidas acerca da desnecessidade de registro para que seja conferida a tutela de proteção pretendida. Segundo o acórdão, questões como a do caso trazido devem ser sempre analisadas visando a inibir o aproveitamento parasitário e confusão gerada entre os consumidores, com o intuito de coibir as práticas de concorrência desleal.

Cumpre referir, por fim, que o caso ainda não transitou em julgado, estando pendente de recursos. Destarte, como os elementos fáticos já foram analisados, e considerando o teor do enunciado da súmula número 7 do Superior Tribunal de Justiça ${ }^{107}$, dificilmente o caso será novamente analisado naquele Tribunal Superior.

103 PORTILHO, 2014, Disponível em: <http://www.dportilho.com.br/o-projetode-lei-do-senado-para-coibir-a-concorrencia-parasitaria-\%E2\%80\%93-ousera-o-aproveitamento-parasitario/>. Acesso em: 27 out. 2018.

104 JABUR; SANTOS, 2007, op. cit., p. 379.

105 PORTILHO, 2014. Disponível em: <http://www.dportilho.com.br/o-projetode-lei-do-senado-para-coibir-a-concorrencia-parasitaria-\%E2\%80\%93-ousera-o-aproveitamento-parasitario/>. Acesso em: 27 out. 2018.

106 Idem.

107 A pretensão de simples reexame de prova não enseja recurso especial. 
Seguindo com a análise de casos, oportuno analisar recente caso que chegou até o Superior Tribunal de Justiça ${ }^{108}$ e no qual os Julgadores entenderam pela não caracterização de concorrência desleal e consequente não violação do trade dress.

Na situação, a empresa Nestlé Brasil Ltda. ajuizou demanda inibitória cumulada com perdas e danos em face da empresa BRF - Brasil Foods S/A. Aduziu a autora que a empresa oponente teria copiado o trade dress do produto "Chandelle", ao comercializar seu produto em embalagem muito semelhante ao iogurte popularmente conhecido no mercado. Para melhor ilustrar o ocorrido, abaixo imagens dos produtos em questão:

Fotografia 7- Iogurte da empresa Nestlé Brasil Ltda. ${ }^{109}$

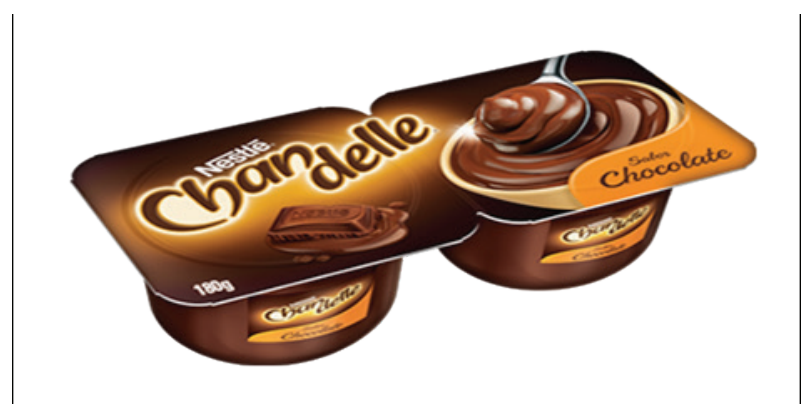

108 BRASIL. Superior Tribunal de Justiça. Recurso Especial no 1591294 . Relator: Ministro Marco Aurélio Bellizze. Brasília, 13 mar. 2018. Disponível em: <https://ww2.stj.jus.br/processo/revista/documento/mediado/?compone nte $=$ ITA\& sequencial $=1683762 \&$ num_registro $=201400253379 \&$ data $=201$ 80313\&formato=PDF $>$. Acesso em: 15 maio 2018.

109 Imagem disponível em https://www.nestle.com.br/images/default-source/produtos/chandelle-chocolate4e4f3d0a5e2243d5b04386313e5c101a. png?sfvrsn=44b526dd_2, acesso em 28/05/2018 
Fotografia 8 - Iogurte da empresa BRF - Brasil Foods S.A. ${ }^{110}$



A empresa demandada no caso (BRF - Brasil Foods) alegou que os elementos da embalagem sequer seriam passíveis de registro para utilização exclusiva, assim como que não restou demonstrado que havia anterioridade na utilização do conjunto visual. Ao julgar o caso, o Ministro relator ressaltou que a mera semelhança entre os produtos não caracteriza ato de concorrência desleal, e entendeu por julgar improcedente a demanda ajuizada, em razão da não comprovação do dano.

Conforme já dito, em que pese não haja no ordenamento jurídico pátrio a possibilidade de registro do trade dress, tal qual ocorre com a marca e com o nome empresarial, não significa que tal bem imaterial deva ficar sem proteção quando violado. Pelo contrário, deve-se buscar a tutela jurisdicional, principalmente porque a violação do conjunto-imagem pode provocar desvio de clientela.

110 Imagem disponível em http://www.batavo.com.br/wp-content/ uploads/2016/10/Sobremesa-Lactea-Cremosa-Sabor-Chocolate_Chocomilk_200g-1.png, acesso em 28/05/2018 
É incontroverso, contudo, que a análise da questão de imitação se dá no caso concreto, constituindo-se questão de fato $^{111}$, tal como no julgado supramencionado.

Logo, para que o empresário que sofreu o ilícito de imitação do trade dress do produto ou estabelecimento consiga obter a tutela jurídica pleiteada, deverá comprovar em processo judicial a prática de concorrência desleal pelo oponente, por meio de dilação probatória, de modo que a não demonstração ensejará a improcedência da ação.

Assim, por oportuno referir que quando houver dúvidas sobre a existência ou não de imitação deve sempre prevalecer a impressão visual. ${ }^{112}$ Isto quer dizer que mesmo que o concorrente que está praticando o ato de concorrência desleal alegue não haver confusão entre os estabelecimentos ou produtos, o critério a definir deve ser o fator visual, e não o nome dado ao estabelecimento ou qualquer outro fator.

Ainda, importante ressaltar que a existência ou não de confusão deve ser apreciada de modo a não identificar somente as semelhanças ou diferenças, mas também a natureza do produto, o meio em que mais utilizado assim como as circunstâncias que levam o consumidor a adquirir tal produto. ${ }^{113}$

Atinente à indenização devida em caso de comprovação de concorrência desleal, tem seu fundamento trazido no artigo 209 da Lei de Propriedade industrial. Conforme afirma Cerqueira da Gama, responde pelo dano não apenas quem tem a intenção de violar o direito alheio ou de causar prejuízo, mas também quem causa o dano pautado em imprudência ou negligência. ${ }^{114}$

111 CERQUEIRA, João da Gama. Tratado de propriedade industrial. Volume II. Ver. Atual. Por Newton Silveira e Denis Borges Barbosa. Rio de Janeiro: Lumen Juris, 2012. p. 50.

112 Ibidem, p. 49.

113 Ibidem, p. 51.

114 Ibidem, p. 285. 
Por fim, será analisado mais um caso concreto de suposta imitação de trade dress, através do Recurso Especial no 1677787/ $\mathrm{SC}^{115}$, de relatoria da Ministra Nancy Andrighi do Superior Tribunal de Justiça.

No caso referido, as empresas Honda Giken Kogyo Kabushiki Kaisha e Moto Honda da Amazônia LTDA. ajuizaram ação em face da concorrente Garthen Indústria e Comércio de Máquinas LTDA., alegando concorrência desleal, porquanto esta última estaria fabricando motores com designs característicos dos motores Honda, ou seja, violando o conjunto imagem.

Importante visualizar ambos os motores, reproduzidos através das imagens abaixo:

Fotografia 9: motor Honda GX $\mathrm{G}^{116}$



115 BRASIL. Superior Tribunal de Justiça. Recurso Especial no 1677787. Relator: Ministra Nancy Andrighi. Dje. Brasília, 02 out. 2017. Disponível em:

$<$ https://ww2.stj.jus.br/processo/revista/documento/mediado/?compone nte $=$ MON\&sequencial $=73822866 \&$ num_registro $=201502797049 \&$ data $=2$ 0170622\&formato=PDF $>$. Acesso em: 15 maio 2018.

116 Imagem disponível em https://www.gensetec.com.br/motor-a-gasolina/ motor-honda-gx160-h1qebr-partida-eletrica-5-5-hp, acesso em 27/10/2018. 


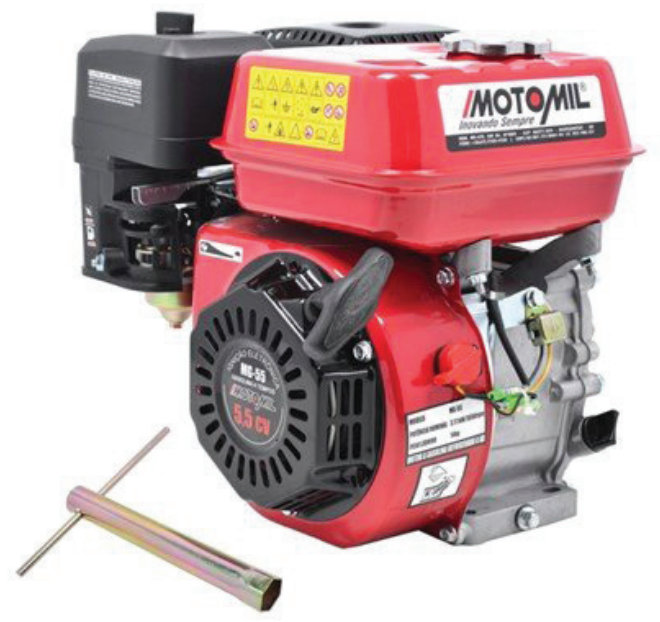

O Juiz de primeiro grau entendeu por acolher a tese de concorrência desleal, julgando procedente a ação, para determinar que a ré cessasse a comercialização, importação, exibição e distribuição dos motores. Condenou, ainda, ao pagamento de indenização em face da ocorrência de concorrência desleal, assim como para recolher do mercado os motores já fabricados, sob pena de multa diária. Destarte, a empresa Indústria e Comércio e Máquinas LTDA., recorreu ao Tribunal de Justiça de Santa Catarina, que reformou a decisão para julgar improcedentes os pedidos. O Tribunal entendeu que não havia na hipótese confusão entre os clientes, na medida em que a marca "Honda" era famosa no mercado. Contudo, reconheceu a similitude entre os dois motores (conjunto-visual). Em prosseguimento, a empresa supostamente lesionada interpôs recurso especial ao STJ.

117 Imagem disponível em https://www.anhangueraferramentas.com.br/ produto/motor-5-5hp-a-gasolina-eixo-horizontal-4-tempos-mg-55-motomil-96582, acesso em 27/10/2018. 
No bem fundamentado julgamento lançado pelo STJ, a relatora levou em consideração para a sua decisão o requisito extrínseco, ou seja, o conjunto visual do segundo motor, já que este em muito se assemelhava ao primeiro, de modo a gerar confusão visual e consequentemente desvio de clientela. Outro fator importante levado em consideração foi o de que as empresas eram concorrentes diretas, ou seja, atuam no mesmo ramo de atividade. Outrossim, ressaltou que a ré possuía produtos inferiores, o que tornava a conduta mais reprovável, pois estaria se utilizando do renome da empresa Honda, que possui clientela fiel, para captar a mesma.

A Relatora ainda destacou em seu voto que quando o conjunto-imagem da empresa é bem sucedido, os produtos são conhecidos por seu alto grau distintivo, de modo que o copiador tende a ter mais sucesso ao confundir os clientes.

Em relação à competência para o julgamento de causas envolvendo trade dress, o STJ, em julgamento de recurso repetitivo, através do REsp 1527232/SP (Tema 950) ${ }^{118}$ restou fixado que é da Justiça Estadual, na medida em que não havendo registro no INPI, autarquia federal, não há interesse da União no julgamento das causas com tal temática.

Destaque-se, desse modo, a relevância da comprovação dos elementos fáticos pelo empresário sofredor do dano, sob pena de ver seu direito violado sem direito de defesa. Conforme visto, a ausência de previsão legal e de órgão registral para o trade dress é um obstáculo à tutela preventiva, mas não é um empecilho para se buscar a proteção legal repressiva, eis que, em se tratando o

118 BRASIL. Superior Tribunal de Justiça. Recurso Especial no 1527232. SS Comércio de cosméticos e produtos de higiene pessoal LTDA. Natura Cosméticos S/A. Relator: Ministro Luis Felipe Salomão. Dje. Brasília, 05 fev. 2018. Disponível em: <https://ww2.stj.jus.br/processo/revista/documento $/$ mediado $/$ ?componente=ATC $\&$ sequencial $=79955021 \&$ num_regis tro $=201500535587 \&$ data $=20180205 \&$ tipo $=5 \&$ formato $=P D F>$. Acesso em: 15 maio 2018. 
conjunto-imagem de um bem imaterial criado pelo empresário, deve ser destinatário de proteção jurídica em caso de dano e desvio de clientela, do mesmo modo que os demais bens tutelados pela propriedade industrial.

\section{CONSIDERAÇÕES FINAIS}

Conforme discorrido, existe um instituto jurídico chamado trade dress ou conjunto-imagem, que significa o modo peculiar pelo qual um produto ou um estabelecimento se apresenta ao mercado. Ademais, este elemento imaterial, ao contrário dos demais bens tutelados pelo direito da propriedade industrial, não possui registo no Instituto Nacional de Propriedade Industrial, o que fragiliza a sua proteção.

Não existe previsão legal específica que seja tratado como ilícito a violação ao trade dress, tampouco a lei o define. De toda a sorte, o Brasil é signatário da Convenção da União de Paris, na qual se comprometeu a reprimir todas as formas de concorrência desleal, que são as práticas contrárias à boa-fé nas relações comerciais.

Assim, encontrou-se um meio para a proteção do conjunto-imagem do produto ou do estabelecimento, em que pese a ausência de previsão legal no ordenamento jurídico brasileiro: a caracterização da concorrência desleal. Isto significa que o agente econômico que se vê sendo copiado poderá buscar tutela jurisdicional alegando concorrência desleal por meio de um processo judicial. Ou seja, para que o empresário consiga ver seu bem protegido, deverá comprovar que o agente econômico concorrente age em desconformidade com as práticas leais comerciais.

Logo, evidente que existe a necessidade de convencimento do Órgão julgador, assim como que cada Juiz utilizará um entendimento, dando margem à insegurança jurídica. Contudo, em que pese este infortúnio, deve-se ponderar os lados positivos existentes. Em havendo eventual definição legal, estar-se-ia li- 
mitando o instituto do trade dress, que a todo o momento pode ser reinventado e amplificado pela mente humana.

A ocorrência ou não de concorrência desleal, a possibilitar a própria proteção do trade dress, deve ser vista à luz de cada caso concreto, com necessidade de dilação probatória em processo judicial, na medida em que não existe órgão administrativo a proteger este elemento. Portanto, não há de se falar em proteção ao conjunto-imagem sem processo judicial.

Portanto, ao que parece, a ausência de previsão e proteção legal é de um lado um problema, porque facilita a imitação do conjunto-imagem e atrela a proteção a um processo judicial, e de outro uma liberdade, porque não limita as formas de trade dress que poderão surgir.

\section{REFERÊNCIAS BIBLIOGRÁFICAS}

ASCENSÃO, José de Oliveira. Concorrência desleal. Coimbra: Almedina, 2002.

BARBOSA, Denis Borges: Uma introdução à propriedade intelectual, 2. ed. Rio de Janeiro: Lumen Juris, 2003.

. Tratado de propriedade intelectual. Rio de Janeiro: Lumen Juris, 2013. v. 1.

Bittar, Carlos Alberto. Teoria e prática da concorrência desleal. São Paulo: Saraiva, 1989.

BITTAR, Carlos Alberto; BITTAR FILHO, Carlos Alberto. Tutela dos direitos da personalidade e dos direitos autorais nas atividades empresariais. São Paulo: Revista dos Tribunais, 1993.

Tratado de propriedade industrial. Ver. Atual. Newton Silveira e Denis Borges Barbosa. Rio de Janeiro: Lumen Juris, 2012. v. 2.

BRASIL. Lei no 9.279 de 14 de maio de 1996, disponível em http:// www.planalto.gov.br/ccivil_03/Leis/19279.html.

. Superior Tribunal de Justiça. Recurso Especial no 1677787. Relator: Ministra Nancy Andrighi. Dje. Brasília, 02 out. 2017. Disponível em: https://ww2.stj.jus.br/processo/revista/documento/mediado/?co 
mponente $=$ MON $\&$ sequencial $=73822866 \&$ num_registro $=20150279704$ 9\&data=20170622\&formato=PDF $>$. Acesso em: 15 maio 2018.

. Superior Tribunal de Justiça. Recurso Especial no 1591294. Relator: Ministro Marco Aurélio Bellizze. Brasília, 13 mar. 2018. Disponível em: <https://ww2.stj.jus.br/processo/revista/documento/me diado/?componente=ITA\&sequencial $=1683762 \&$ num_registro $=20140$ 0253379\&data $=20180313 \&$ formato $=P D F>$. Acesso em: 15 maio 2018.

CERQUEIRA, João da Gama. Tratado da propriedade industrial. Rio de Janeiro-Editora:Revista Forense, 1946. v.1.

COELHO, Fábio Ulhoa. Manual de direito comercial: direito de empresa. 23. ed. São Paulo: Saraiva, 2011.

. Curso de direito comercial: direito de empresa. 18. ed. São Paulo: Saraiva, 2014. V. 1.

Manual de direito comercial: direito de empresa. 28. ed. Ver., atual. e ampl. São Paulo: Revista do Tribunais, 2016.

FAZZIO, Junior Waldo. Manual de direito comercial. 7. ed. São Paulo: Atlas, 2006.

FALCONE, Bruno. Propriedade industrial e defesa da concorrência: convergência principiológica. Curitiba: Juruá.

GONÇALVES, Luís M. Couto. Manual de direito industrial: patentes, marcas, concorrência desleal. Coimbra: Almedina, 2005.

GUSMÃO, Jose Roberto D'affonseca; H'ANENS, Laetitia Maria Alice Pablo. Breves comentários sobre a protecão ao trade dress no Brasil. Revista dos Tribunais, São Paulo, v. 1, n. 1, p.585-597, maio 2012. Mensal.

HAMMES, Bruno Jorge. 0 direito de propriedade intelectual. 3. ed. São Leopoldo: Unisinos, 2002.

LABUR, Wilson Pinheiro; SANTOS, Manoel J. Pereira dos. (coord.). Propriedade intelectual: criações industriais, segredos de negócio e concorrência desleal. São Paulo: Saraiva, 2007. p. 378.

MANARA, Cecília. A proteção jurídica do "trade dress" ou "conjunto-imagem". Rio de Janeiro: Lumen Juris, 2008.

PORTILHO, Deborah. O projeto de lei do senado para coibir a concorrência parasitária - ou será o aproveitamento parasitário? Revista Científica Virtual da Escola Superior de Advocacia da Oab-SP, São Paulo, n. 9, p.18-35, jan. 2014. Disponível em: <http://www.dportilho.com. 
br/o-projeto-de-lei-do-senado-para-coibir-a-concorrencia-parasitaria-\%E2\%80\%93-ou-sera-o-aproveitamento-parasitario/>.

SILVA, Pedro Sousa e. Direito comunitário e Propriedade Industrial: O princípio do esgotamento dos direitos. Coimbra: Coimbra, 1996.

SILVEIRA, Newton. Propriedade intelectual: propriedade industrial, direito de autor, software, cultivares, nome empresarial, abuso de patentes. 5. ed. São Paulo: Manoele, 2014. p.103.

Site www.batavo.com.br

Site www.nestle.com.br

Site https://courses2.cit.cornell.edu/sociallaw/student_projects/Tradedresspage 2.html

Site http://www.planalto.gov.br/ccivil_03/Leis/L9279.htm

Site http://www.inpi.gov.br/legislacao-1/cup.pdf

Site http://www.planalto.gov.br/ccivil_03/Leis/19279.html

Site https://www.lojaslivia.com.br/produto/shampoo-alisena-amido-de-milho-300-ml-lisos-e-soltos-83594

Site http://www.soubarato.com.br/produto/129320216/amido-de-milho-maizena-500g

Site https://www.nestle.com.br/images/default-source/produtos/chandelle-chocolate 4 e $4 \mathrm{f} 3 \mathrm{~d} 0 \mathrm{a} 5 \mathrm{e} 2243 \mathrm{~d} 5 \mathrm{~b} 04386313 \mathrm{e} 5 \mathrm{c} 101 \mathrm{a}$. png?sfvrsn=44b526dd_2, acesso em 28/05/2018

Imagem disponível em http://www.batavo.com.br/wp-content/ uploads/2016/10/Sobremesa-Lactea-Cremosa-Sabor-Chocolate_ Chocomilk_200g-1.png, acesso em 28/05/2018

Site https://www.anhangueraferramentas.com.br/produto/motor-5-5hp-a-gasolina-eixo-horizontal-4-tempos-mg-55-motomil-96582

SOARES, José Carlos Tinoco. Concorrência desleal. São Paulo: Resenha Tributária, 1990.

. Concorrência desleal vs. Publicidade comparativa e enganosa, patentes de invenção, de modelos e de desenhos, visual interno e externo do estabelecimento, publicidade reprodutiva e imitativa. São Paulo, Ed, Resenha tributária, 1990. p. 21. 
-___-_Concorrência desleal": "Trade Dress" e/ou "Conjunto-Imagem" (visual do objeto, do produto, de sua exteriorização e do estabelecimento). São Paulo: Edição do autor, 2004.

VIVANTE, Cesare. Instituições de Direito Comercial: tradução e notas de Ricardo Rodrigues Gama. Campinas: LZN, 2003.

XAVIER, Vinicius de Almeida. As possibilidades de proteção ao trade dress. Direito \& Justiça, [s.l.], v. 41, n. 2, p. 248-263, 29/jul., 2015. EDIPUCRS. http://dx.doi.org/10.15448/1984-7718.2015.2.13642. 